\title{
A Prehistoric Caddo Site on Black Fork Creek, Upper Neches River Basin, Smith County, Texas
}

Timothy K. Perttula

Heritage Research Center, Stephen F. Austin State University

Bo Nelson

Heritage Research Center, Stephen F. Austin State University

Follow this and additional works at: https://scholarworks.sfasu.edu/ita

Part of the American Material Culture Commons, Archaeological Anthropology Commons, Environmental Studies Commons, Other American Studies Commons, Other Arts and Humanities Commons, Other History of Art, Architecture, and Archaeology Commons, and the United States History Commons

Tell us how this article helped you.

This Article is brought to you for free and open access by the Center for Regional Heritage Research at SFA ScholarWorks. It has been accepted for inclusion in Index of Texas Archaeology: Open Access Gray Literature from the Lone Star State by an authorized editor of SFA ScholarWorks. For more information, please contact cdsscholarworks@sfasu.edu. 
A Prehistoric Caddo Site on Black Fork Creek, Upper Neches River Basin, Smith County, Texas

\section{Creative Commons License}

\section{(c) (i) (9)}

This work is licensed under a Creative Commons Attribution-NonCommercial 4.0 International License 


\title{
A Prehistoric Caddo Site on Black Fork Creek, Upper Neches River Basin, Smith County, Texas
}

\author{
Timothy K. Perttula and Bo Nelson
}

\section{INTRODUCTION}

During the course of recent archaeological survey investigations for a proposed waterline, a previously unrecorded prehistoric Caddo siteLakewood Gardens (41SM425) —was found near, but outside the right-of-way and construction easement of, the proposed waterline (Nelson and Perttula 2010). This article provides summary details about the site, hopefully adding information to the sparse archaeological record of prehistoric Caddo sites along Black Fork Creek.

The site is situated on a natural upland rise (440 feet amsl) overlooking the Black Fork Creek floodplain less than $200 \mathrm{~m}$ to the north. Black Fork Creek is in the upper Neches River basin; the creek flows west into Prairie Creek, which enters the Neches River about $10 \mathrm{~km}$ to the west of the site. This area is in the Post Oak Savannah (Perttula and Nelson 2004:Figure 2). Before the mid- to late 19th century, the swampy Black Fork Creek floodplain would have been covered with an oak-hickory forest, with more mesic hardwoods, including various oaks, maple, sweetgum, ash, and elm (Hatherly 1993; Perttula and Nelson 2004). The Post Oak Savanna vegetation would have been dominated by a variety of fire-tolerant oaks and hickory on upland landforms. The upland landforms in this part of Smith County area have Eocene-aged Queen Sparta, Tyler Greenstone Member, and Weches Formation interbedded deposits of sand and clays (Bureau of Economic Geology 1965).

\section{ARCHAEOLOGICAL FINDINGS}

All six shovel tests excavated at the Lakewood Gardens site contain prehistoric Caddo ceramic and lithic artifacts in moderately thick (ca. $80 \mathrm{~cm}$ ) Bresner soils (Hatherly 1993:22). These soils have yellowish-brown fine sandy loam A- and E-horizons overlying a strong brown clay subsoil. The prehistoric Caddo occupation at the site is shallowly and naturally buried in this soil at depths between 40-80 $\mathrm{cm}$ bs; no artifacts were found in the shovel testing between $0-40 \mathrm{~cm}$ bs. The density of prehistoric artilacts in the shovel testing is 1.83 per positive shovel test, or a relatively low density of ca. 14.6 artifacts per $\mathrm{m}^{2}$. The size of the landform and the distribution of positive shovel tests suggests the Lakewood Gardens site covers ca. 1 acre $\left(4000 \mathrm{~m}^{2}\right)$.

Prehistoric grog-tempered Caddo sherds were recovered in two shovel tests (ST 4 and ST 6) between $40-80 \mathrm{~cm}$ bs (Table 1). All three sherds are from the body of moderately thick-walled vessels, probably jars. One of the sherds has parallel brushing on its exterior surface, suggesting it came from a cooking or storage jar; the brushing probably was oriented vertically on the vessel body.

In this part of Smith County, Texas, brushed jars were likely manulactured and used first in the Middle Caddo period (cf. Perttula and Nelson 2004; Walters 2008), from ca. A.D. 1200-1400, and this may be the likely period when the Lakewood Gardens site was occupied by prehistoric Caddo peoples, since just to the north in the Sabine River basin, Caddo groups had abandoned this region about A.D. 1400 (cf. Walters 2008). Late (ca. A.D. 1400-1650) and Historic (post-ca. A.D. 1650) Caddo groups in the upper Neches River valley to the south and west (see Anderson et al. 1974) continued to make brushed ceramic vessels, however, until they abandoned the area in the early 18th century.

Chipped stone tools were knapped and/or resharpened at the Lakewood Gardens site, and certain tools were used here as well. Evidence of chipped stone tool manufacture and use includes one bilateral and unifacially used/worn expedient flake tool (ST 4, 40-60 cm bs)-probably used to eut, slice, and lightly scrape hides and packages of meat - made from a non-local grayish-brown chert raw material. Knapping debris consists of small (less than $6.4 \mathrm{~mm}$ ) 
Table 1. Detailed Analysis of Ceramic Sherds from the Lakewood Gardens Site (4ISM425).

\begin{tabular}{llllcll}
\hline $\begin{array}{l}\text { Provenience } \\
\text { (cm bs) }\end{array}$ & $\begin{array}{l}\text { Sherd } \\
\text { Type }\end{array}$ & Temper & FC & ST & $\begin{array}{c}\text { Th } \\
(\mathrm{mm})\end{array}$ & Decoration \\
\hline ST 4, 40-60 & body & grog & C & - & 9.6 & plain \\
ST 4, 60-80 & body & grog & G & 1 SM & 7.2 & parallel brushed \\
ST 6, 60-80 & body & grog & E & - & 7.7 & plain \\
\hline
\end{tabular}

$\mathrm{FC}=$ firing condition (following Teltser [1993]); $\mathrm{C}$ and $\mathrm{E}$ =incompletely oxidized during firing; $\mathrm{G}$, fired in a reducing environment, and cooled in the open air; ST=surface treatment; I=interior; SM=smoothed

flakes on locally available lithic raw materials that have both smooth cortical ( $\mathrm{n}=2$; probably gathered from stream gravels) and non-cortical $(n=5)$ exterior surfaces. These flakes are from petrified wood $(n=4)$ and quartzite $(\mathrm{n}=3)$; one of the quartzite pieces came from a heat-treated core or tool.

\section{SUMMARY}

The Lakewood Gardens site (41SM425) is a shallowly buried Middle and/or Late Caddo period habitation site recently discovered in the Black Fork Creek valley in the upper Neches River basin. The lact that the site appears to contain both intact and buried archacological deposits and Caddo habitation debris suggests that the site may contain-upon further investigation, provided it is not disturbed by future development activities-features from a domestic occupation, including one or more wood structures, outdoor activity areas with ramadas and arbors, and localized trash deposits.

\section{REFERENCES CITED}

Anderson, K. M., K. Gilmore, O. F. McCormick, and E. P. Morenon

1974 Archaeological Investigations at Lake Palestine. Texas. Contributions in Anthropology 11. Department of Anthropology, Southern Methodist University, Dallas.
Bureau of Economic Geology

1965 Geologic Atlas of Texas, Tyler Sheet. Bureau of Economic Geology, The University of Texas at Austin.

Hatherly, D. T.

1993 Soil Sunvey of Smith County, Texas. United States Department of Agriculture, Soil Conservation Service, in cooperation with the Texas Agricultural Experiment Station and the Texas State Soil and Water Conservation Board.

Nelson, B. and T. K. Perttula

2010 Archeological Survey of a Proposed Water Line Project in Smith County, Texas. Letter Report No. 247. Archeological \& Environmental Consultants. LLC, Austin.

Perttula, T. K. and B. Nelson

2004 Woodland and Caddo Archeology at the Broadway or Kanduts 'ah Kuhnihdahahdisa' Site (41SM73) on the City of Tyler-Lake Palestine WTP Project. Smith County, Texas. Report of Investigations No. 50. Archeological and Environmental Consultants, LLC. Austin.

Teltser, P. A.

1993 An Analytic Strategy for Studying Assemblage-Scale Ceramic Variation: A Case Study from Southeast Missouri. American Antiquity 58(3):530-543.

Walters, M.. with contributions from L. G. Cecil, L. S. Cummings, J. P. Dering, J. R. Ferguson, M. D. Glascock, T. K. Perttula, L. Schniebs, H. J. Shafer, J. Todd, and C. P. Walker

2008 Life on Jackson Creek. Smith County, Texas: Archeological Investigations of a 14th Century Caddo Domicile at the Leaning Rock Site (41SM325). Caddo Archeology Journal 17:1-114. 